\title{
The Conceptual Metaphor of Governance in The Governance of China
}

\author{
Xiaochuan Tian, Yunhao Ba, Xinyu Zhang \\ East China University of Science and Technology, Shanghai, China \\ Email: 1666165631@qq.com
}

How to cite this paper: Tian, X.C., Bo, Y.H. and Zhang, X.Y. (2021) The Conceptual Metaphor of Governance in The Governance of China. Open Access Library Journal, 8: e8147.

https://doi.org/10.4236/oalib.1108147

Received: November 2, 2021

Accepted: November 19, 2021

Published: November 22, 2021

Copyright $\odot 2021$ by author(s) and Open Access Library Inc.

This work is licensed under the Creative Commons Attribution International License (CC BY 4.0).

http://creativecommons.org/licenses/by/4.0/

\begin{abstract}
Conceptual metaphor theory emphasizes the fact that metaphor is essentially a basic way of thinking and that it has the function of constructing concepts and can be powerfully persuasive. This is why political discourse often uses conceptual metaphors to make important political ideas more accessible and acceptable to the general public, which in turn can lead to real action. Citing examples from The Governance of China, this article focuses on the conceptual metaphors of governance, analyses the conceptual metaphors surrounding "road confidence" and "great struggle", and discusses the English translation of the metaphors.
\end{abstract}

\section{Subject Areas}

Politics

\section{Keywords}

Conceptual Metaphor, Political Metaphor, Persuasion, Governance

\section{Introduction}

Metaphor is a common form of linguistic expression that can be found in all languages. Metaphorical expressions are based on the similarities or associations that can be perceived or constructed between different things; their use enables people to talk about one thing in relation to another. The features of metaphorical production and use extend people's ability to feel, reason and communicate in a uniquely human way (Demjén and Semino 2017) [1].

The importance of metaphor has been agreed since ancient times, which is why the study of metaphor has a long history. In academic circles, the study of metaphor is often traced back to Aristotle in ancient Greece in the 4th century BC. In his Poetics, Aristotle saw metaphor as a rhetorical device that refers to 
one thing by another, using one word for another. Aristotle also says: "The greatest thing by far is to be a master of metaphor" (Landau 2017: 14) [2]. It should be noted, however, that Aristotle shared the dominant view of his time that metaphor was hardly conducive to such a serious activity as the search for truth. The ancient Greek theory of knowledge held that logos was basically sufficient to describe anything that existed (Blumenberg 2010) [3]. In Landau's (2017: 14) [2] view, it was also this understanding that led to metaphor being effectively and often underappreciated and marginalised in the centuries after Aristotle, and in the Enlightenment era it was outright ridiculed by philosophers. Thomas Hobbes (1651/1968) [4] and John Locke (1947/1689) [5] accused metaphors of using words that deviated from their proper meaning and caused interference with clear reasoning.

Traditionally, the academic research on metaphor was mostly concerned with the rhetorical effects. Since 1980s, researchers began to pay more attention to the cognitive aspect of metaphor, and have had many significant discoveries. There are also some researches that are corpus-based. (Ding 2021) [6] However, the researches that examine the metaphors for governance are few. This article centers around the conceptual metaphor theory (Johnson and Lakoff 1980) [7], concentrating on JOURNEY metaphor and WAR metaphor with a view to disclosing how metaphors influence people conceptually.

\section{The Cognitive Turn in Metaphor and Conceptual Metaphor}

Although the role of metaphor beyond rhetoric in understanding and discovering the objective world has been debated, the research interest it has stimulated has extended from rhetoric to philosophy, ethics, political science, linguistics, literary and cultural criticism, psychology and cognitive science, and has given rise to debates about the status of metaphor: whether it is good or bad, ordinary or extraordinary, enlightening or confusing, and whether it is connected to other aspects of language and thought, and other aspects of language and thought (Demjén and Semino 2017) [1].

Unlike Aristotle, Hobbes and Locke, there are important philosophers who no longer treat metaphor as a mere modifying device in language, such as Friedrich Nietzsche and Max Black. Nietzsche (1873/1979) [8] claims that because the human mind cannot directly comprehend truth, almost all of what man thinks is true comes from a concentration of several metaphors. Nietzsche contradicts the ancient Greek theory of knowledge: metaphor is now the engine of meaning, while logos has become rare (Mark J. Landau) [2]. There are other scholars who have discovered the central role of metaphor in their observations of human things, such as Ernst Cassirer (1946) [9], Susanne Langer (1979) [10], and Hannah Arendt (1978) [11]. These scholars have shown in their own research that metaphor has permeated all aspects of cognition and culture.

The various debates that emerged around metaphor developed a focus in the 
late 1970s and early 1980s, represented by Metaphor and Thought (1979/1993), edited by Andrew Ortony [12], and Metaphors We Live By (1980) [7], written by George Lakoff and Mark Johnson. Metaphors We Live By (1980) [7] focuses on metaphor first and foremost as a cognitive phenomenon and as a central component of thinking. It announced a cognitive turn in the study of metaphor. Metaphors are everywhere, not only in language but also in thought and action. The everyday conceptual systems we use to think and act are, by their very nature, metaphorical.

We talked earlier about how scholars such as Cassirer, Langer and Arendt all began to emphasise the significance of metaphor for cognition and culture, but they did not explain clearly how metaphor constructs meaning at a basic cognitive level. The emergence of conceptual metaphor theory has led to an explanation of the mechanisms by which metaphor works at a basic level of cognition. What distinguishes conceptual metaphor from other theories of metaphor is that it treats metaphor as a conceptual tool for structuring, reconstructing and even creating reality. Take LIFE IS A JOURNEY as an example. This metaphor is widely used in both English and Chinese cultures. Rather than reflecting the perception of something in isolation, it triggers a systematic perception of interconnected things: we think about where we start and where we go, about how to walk on the straight and narrow, about making plans and mapping out routes, and even about alternative paths. We also accept and use the metaphor LIFE IS A THEATRE PLAY, as expressed at the beginning of the soliloquy of William Shakespeare's idyllic comedy AS YOU LIKE IT, where men and women have their own roles, and young and old exit the stage in turn, and life has its own stages, life has its own flavours... Thus we think about how we can play this play well. The two metaphors LIFE IS A JOURNEY and LIFE IS A THEATRE PLAY have the same source domain, but because the target domain is different, they inspire a different series of related concepts, which in turn induces different perspectives on life, and even different attitudes and actions. Therefore, the importance of studying conceptual metaphors is to discover their possible framing effects on people's thoughts and actions, and to analyse their mechanisms of action.

Even though a metaphor may exist in two languages, it may function differently in two cultural-ideological contexts (Kovecses 2005) [13].

\section{Conceptual Metaphor for Governance}

\subsection{Political Metaphor}

In his On Rhetoric, Aristotle grouped the way of argumentative persuasion into three categories, namely ethos, pathos and logos. Metaphor can be said to function as all three of these categories at once. Firstly, metaphorical language can move the mind and bring the listener into the state of mind desired by the speaker, thus giving the speaker and the listener, mainly the listener, a sense of being one and opening the way for the transmission of concepts. Secondly, de- 
velopments in neuroscience and cognitive science clearly show that rational thought is possible only if emotional experience precedes cognitive processes (Marcus 2002) [14]. It is emotion that allows one to prioritise, so that one can focus on what is most important. In this way, metaphors are able to reason after moving with emotion, enabling a link between metaphor and reason. Finally, metaphors are also able to link temperament. Several studies have shown that the relationship between the use of language that evokes or inspires images and the creation of a charisma that attracts a crowd of speakers cannot be underestimated. In this way, metaphor is a tactic that can be used to persuade the listener in a sensible and reasonable way, in the context of "justice". The potential of political metaphors to influence people's thoughts and actions, and their common and unquestionable use, were valued by political language long before their function of constructing meaning and shaping cognition was recognised through conceptual metaphor theory. When used as a cognitive tool, political metaphors, more than any other metaphor, are intended to create a force for change in reality.

The Governance of China profoundly reflects the development of the theory and practice of state governance in the new era, and the language used is simple yet profound, vivid and thought-provoking, and highly distinctive. One of the linguistic features worth studying is the good use of metaphors to express the strategies and ideas of governance. For example, "dào căo rén," "dìng dìng zĩ," "shí liú ž̌," "kěn yìng gŭ tóu," and "gōng chéng bá zhài." These metaphors, from familiar things to profound ideas, have a powerful persuasive effect and generate great power for action. An in-depth study of the metaphorical expressions of Xi Jinping's thoughts on governance will not only help people gain a deeper understanding of Xi Jinping's scientific planning for governance, but also help them learn Xi Jinping's language style, enhance their ability to express themselves in political language and improve their efficiency in promoting work.

We have focused on two of the most prominent conceptual metaphors in the second volume of The Governance of China, namely the JOURNEY metaphor, which is intended to conceptualize events or characteristics of events as a journey or characteristics of a journey, and the WAR metaphor, which is intended to conceptualize events or characteristics of events as a war or characteristics of a war. Volume 2 of The Governance of China contains 99 speeches, talks and addresses by General Secretary Xi Jinping between 18 August 2014 and 29 September 2017 [15], divided into 17 topics.

\subsection{Great Journey}

The JOURNEY metaphor is a representative example analysed by Lakoff and Johnson (1980) [7] in their interpretation of conceptual metaphor theory, and is the most frequently used basic metaphor in our daily lives, so it has high accessibility for concept construction and low cognitive cost for cognitive processing. Moreover, in Chinese political discourse practice, “道路” has become a metaphor with great political connotations, as it is about the political direction and 
development of the country and the realistic choices of the people. As what is said in The Governance of China, Volume 2, the direction determines the path and the path determines the destiny. Therefore, the metaphor of JOURNEY appears very frequently in the corpus we have collected, with as many as 56 expressions using the word "dào lù" as a metaphor, and others containing the words "guǐ dào", "lù xiàn" and "zhēng tú". Together, these metaphors present a sense of confidence on a great journey.

1) dèng xiăo píng tóng zhì chóng gāo xiān míng yòu dú jù mèi lì de gé mìng fēng fàn, jiāng jī lì wǒ men zài shí xiàn "liăng gè yī băi nián "fèn dòu mù biāo, shí xiàn zhōng huá mín zhǔ wěi dà fù xìng zhōng guó mèng de zhēng tú shàng fèn yǒng qián jìn.

His lofty revolutionary ideals and charisma will always be an inspiration to us on our path towards the Two Centenary Goals and the Chinese Dream of national rejuvenation.

2) yī qiē xiàng qián zơuu, dōu bú néng wàng jì zǒu guò de lù; zǒu dé zài yuăn, z ǒu dào zài huī huáng de wèi lái, yě bú néng wàng jì zǒu guò de guò qù, bú néng wàng jì wéi shí me chū fā. miàn xiàng wèi lái, miàn duì tiāo zhàn, quán dăng tóng zhì yī dìng yào bú wàng chū xīn, jì xù qián jìn.

We shall move forward, but we shall not forget the path that we have taken in the past. No matter how far we go towards a bright future, we should not forget why we set out in the first place. Facing the future and challenges, all Party members should never forget why we started out and continue marching forward.

3) găi gé bì xū jiān chí zhèng què fāng xiàng, jì bú zǒu fēng bì jiāng huà de lăo lù̀, yě bú zǒu găi qí yì zhì de xié lù.

Reform must keep to the right direction. We must neither follow the old path of a rigid closed-door policy, nor an erroneous path by abandoning socialism.

In the above three examples, the "road" metaphor is used. We know that one of the key features of conceptual metaphors is that when they are mapped, they often do not stop at a single concept, but extend to several related concepts, thus forming a conceptual system. When we think of our cause as a "road", our cause will have a "direction" and a "goal", and we will have to "move forward" and to distinguish between right and wrong.

The successful publication of the English edition of The Governance of China, Volume 2, was made possible by a strong translation team. It is known that the team consisted of 29 translators who have been working in translation for many years, including seven finalizers, one foreign rewriting expert and two foreign experts to assist in the work. The language used in the English translation of this document is therefore accurate and effective. When translating the relevant metaphorical language, it is not just a case of being unchanging, but of carefully identifying and adapting it to the meaning of the original. For example, in the example below, the concept of "dào lù" itself is not transferred to the translation, but still visually conveys the message of the original text accurately. So while we 
value the important role of metaphors in constructing concepts, we also need to consider the different linguistic and cultural habits of using specific metaphors in specific contexts.

4) wǒ men bú duàn zhàn shèng qián jìn dào lù shàng gè zhǒng shì suǒ hăn jiàn de jiān nán xiăn zǔ

China has overcome rarely-seen difficulties and removed barriers to progress.

In short, the use of the JOURNEY metaphor in Volume 2 of The Governance of China successfully builds the concept of "the blueprint has been drawn, the time for struggle is now", which is conducive to a powerful force for action.

\subsection{Great Struggle}

One of the most direct impressions of the article "Meet Challenges Head-on" in Volume 3 of The Governance of China is that the metaphor "dòu zhēng" dominates the entire article and is used throughout. In less than 2000 words, the metaphor "dòu zhēng" appears 56 times. The metaphor "dòu zhēng" is a kind of WAR metaphor. When we read the second volume of The Governance of China, we found that this metaphor also appears very frequently. There are 12 occurrences of the word"dòu zhēng" and 96 occurrences of the word "zhàn luè" alone. Other metaphors of WAR, including "zhèn dì", "duì wǔ" and "wǔ zhuāng”, also appear with great frequency. The message conveyed by these metaphors is, as stated in The Governance of China, Volume 2, that the development of socialism with Chinese characteristics is a long and arduous historical task, and that one must prepare for a great struggle with many new historical characteristics.

5) tuō pín gōng jiān zhàn de chōng fēng hào yĩ jīng chuī xiăng. wǒ men yào lì xià yú gōng yí shān zhì, yăo dìng mù biāo, kŭ gàn shí gàn, jiān jué dă yíng tuō pín gōng jiān zhàn, què băo dào 2020 nián suǒ yǒu pín kùn dì qū hé pín kùn rén kǒu yī dào măi rù quán miàn xiăo kāng shè huì.

We have sounded a clarion call in the battle against poverty. To win this battle, we should have firm resolve and solid goals, and work hard with a downto-earth spirit, to bring reasonable prosperity to all poverty-stricken areas and individuals by 2020 .

In example 5) above, we can see that "chōng fēng hào" and "gōng jiān zhàn" are both WAR metaphors, translated as "clarion call" and "battle", respectively, with a basic conceptual correspondence. When we compare more examples, we found that there are more cases where there is no conceptual correspondence between the original and the English translation of the WAR metaphor than where there is a basic conceptual correspondence between the original and the English translation of the JOURNEY metaphor. For example, in examples 6)-9) below, the WAR metaphors "zhǔ zhèn dì”, "wŭ zhuāng”, "zhàn dòu lì", "zhŭ zhàn chăng", "duì wǔ" and "lǐ ngjūn"are not translated into the English language as WAR metaphors.

6) wǒ shuō guò, hù lián wăng shì dāng qián xuān chuán sī xiăng gōng zuò de zhŭ zhèn dì. 
As I have observed before, cyberspace is a major domain for publicity, thus a focus of competition.

7) huí gù dăng de fèn dòu lì chéng kě yĩ fã xiàn, wǒ men dăng zhī suǒ yí néng gòu bú duàn lì jīng jiān nán kùn kǔ chuàng zào xīn de huī huáng, hěn zhòng yào de yī tiáo jiù shì wǒ men dăng shǐ zhōng zhòng shì sī xiăng jiàn dăng, lǐ lùn qiáng dăng, jiān chí yòng kē xué lǐ lùn wǔ zhuāng guăng dà dăng yuán, gàn bù de tóu năo, shǐ quán dăng shǐ zhōng băo chí tǒng yī de sī xiăng, jiān dìng de yì zhì, qiáng dà de zhàn dòu lì.

The history of the CPC shows that its repeated triumphs over difficulties have a reason-it has always provided strong ideological and theoretical training for Party members and officials, so as to forge a shared faith, a strong will, and great strength throughout the Party.

8) dì sān, jiā qiáng kē jì gòng gěi, fú wù jīng jì shè huì fã zhăn zhŭ zhàn chăng.

Third, we will increase our scientific and technological support to economic and social development.

9) wǒ guó kē jì duì wǔ guī mó shì shì jiè shàng zuì dà de, zhè shì chăn shēng shì jiè jí kē jì dà shī, lịngjūn rén cái, jiān zĩ rén cái de zhòng yào jī chǔ.

China has the largest reserves of scientists and engineers in the world. This offers great possibilities for the emergence of leading masters, scientists and professionals.

The above examples show that WAR metaphors are more common in Chinese expressions and are more easily accepted and appreciated, but the situation is different in English culture. In fact, mechanically rendering these concepts of war in English translations may produce different conceptual associations and cause serious misinterpretations.

\section{Conclusions}

Metaphor is not only a rhetorical device, but also a cognitive one. In political discourse, metaphors can be used to stimulate people's existing concepts through familiar imagery, to activate their habitual ways of thinking, to convey and construct new information in a circuitous way, to achieve a popularising effect of turning the difficult into the easy, the complicated into the simple, and to allow politicians to demonstrate their rational thinking on political issues (Charteris-Black 35) [16], and to generate great real power. At the same time, The Governance of China has always been seen as a window of thought for the world to read and understand China, and when translating political metaphors in it, it is important to take into account the reception of the transplanted language, to be careful with the words, to convey the message accurately and effectively, to touch more truly the dream of China's development and change, to understand more deeply what the Chinese leader thinks and does and the path he has chosen to lead the country. The path chosen and the direction are pursued by the country he leads.

This article has not yet analysed conceptual metaphors other than the JOURNEY 
metaphor and WAR metaphor. This is where our research will cover in the future for a more systematic analysis of metaphors for governance.

\section{Conflicts of Interest}

The authors declare no conflicts of interest.

\section{References}

[1] Demjén, Z. and Semino, E. (2017) Introduction: Metaphor and Language. In: Semino, E. and Demjén, Z., Eds., The Routledge Handbook of Metaphor and Language, Routledge, New York and London, 1-10.

[2] Landau, M.J. (2016) Conceptual Metaphor in Social Psychology: The Poetics of Everyday Life. Routledge, New York and London. https://doi.org/10.4324/9781315312019

[3] Blumenberg, H. (2010) Paradigms for a Metaphorology. Cornell University Press, Ithaca. https://doi.org/10.7591/j.ctt7v7cn

[4] Hobbes, T. (1968) Leviathan. Macpherson, C., Ed., Penguin, New York. (Original Work Published 1651)

[5] Locke, J. (1947) An Essay Concerning Human Understanding. Dent, London. (Original Work Published 1689)

[6] Ding, P. (2021) A Corpus-Based Study of Conceptual Metaphor-On Chinese English Learners' Use of “Wind”. Open Journal of Social Sciences, 9, 448-455. https://doi.org/10.4236/jss.2021.910031

[7] Lakoff, G. and Johnson, M. (1980) Metaphors We Live By. University of Chicago Press, Chicago.

[8] Nietzsche, F. (1979) On Truth and Lies in a Normal Sense. In: Breazeale, D., Trans. and Ed., Philosophy and Truth: Selections from Nietzsche's Notebooks of the Early 1870s, Humanities Press, Atlantic Highlands. (Original Work Published 1873)

[9] Cassirer, E. (1946) Language and Myth. Langer, S., Trans., Harper and Bros, New York.

[10] Langer, S. (1979) Philosophy in a New Key: A Study in the Symbolism of reason, Rite, and Art. Harvard University Press, Cambridge.

[11] Arendt, H. (1978) The Life of the Mind: One: Thinking. Harcourt-Brace Jovanovich, New York

[12] Ortony, A. (Ed.) (1993) Metaphor and Thought. 2nd Edition, Cambridge University Press, New York. https://doi.org/10.1017/CBO9781139173865

[13] Kovecses, Z. (2005) Metaphor in Culture: Universality and Variation. Cambridge University Press, Cambridge. https://doi.org/10.1017/CBO9780511614408

[14] Marcus, G.E. (2002) The Sentimental Citizen: Emotion in Democratic Politics. Penn State University Press, University Park.

[15] Xi, J.P. (2017) Xi Jinping: The Governance of China. Vol. 2, Foreign Languages Press, Beijing.

[16] Charteris-Black, J. (2011) Politicians and Rhetoric: The Persuasive Power of Metaphor. 2nd Edition, Palgrave Macmillan, London.

https://doi.org/10.1057/9780230319899 